\title{
Introduction: Chinese Xin Yimin and Their Descendants in France
}

Claiming Belonging and Challenging the Host Country's Integration Model

\section{中国新移民及其后裔在法国: 归属诉求及对融合 的挑战}

\author{
Ya-Han Chuang \\ Postdoc Fellow, INED
}

Hélène Le Bail

Research Fellow, Sciences Po Paris, CNRS

Aurore Merle

Associate Professor, CY Cergy Pontoise University

As Chinese immigration to Europe continues to grow, the research on the migration patterns and mobility regimes of this population has flourished and diversified (Laczko 2003; Thunø and $\mathrm{Li} 2 \mathrm{O}^{2} \mathrm{O}^{1}$ ). In such a context, France remains the European country where Chinese communities' claims of citizenship have become the most tangible. Since 2010, when the first protest in the Belleville neighborhood of Paris was organized, the "Chinese-French" have been seeking their own space, words and identity within the French social and political landscape. The French case is a key case study today in Europe for analyzing the renewed challenges that host countries face in incorporating migrants' descendants. Indeed, 3 years after the descendants of North African immigrants' first took to the streets to claim their rights, Chinese (and Southeast Asian) descendants' emerging activism signifies a generational turn within the immigrant communities. However, the current situation differs on two points: first, unlike North and sub-Saharan African immigration, where immigrants have suffered systemic racism due to the colonial heritage, Chinese and Southeast

1 Mette Thunø and Li Minghuan are also the initiators of the China-Europe Research Platform on Chinese Migration to and Beyond Europe (CERPE) which promotes and fosters studies on Chinese migration in the continent. 
Asian immigration is historically less subject to the colonial heritage; second, Chinese immigrants and their descendants have long been considered a model minority, yet this label has contributed to their exclusion from the overall definition of French national identity. The case of the Chinese xin yimin 新移民 (new migrants) and their descendants in France therefore offers fresh perspectives on the analyses of ethnic relations in the host countries of Europe.

This special issue aims to highlight the evolving processes of identification and mobilization of the Chinese community in France across different generations, classes and professional groups. While bearing in mind the growing influence of China's diasporic policy (Thunø 2018; Tran and Chuang 2020), transnational practices (Zhou and Hong 2016), and the role of diasporic transnational social spaces in the socialization of Chinese immigrants and their descendants (Ma Mung 2012), this issue returns to what could be considered a more classical approach to migration studies: that of immigrants' inclusion in and sense of belonging to the host society and how migrants, their descendants and the host country negotiate recognition and protection. A particular focus of this issue is the tension that exists between the dominance of the universalist French republican model of integration and the collective claims of the overseas Chinese (Chinese migrants from Mainland China), the Chinese overseas (ethnic Chinese, mainly from Southeast Asia in the case of France) and their descendants in France, as well as the specific problems they encounter. This special issue thus contributes to the broader field of diaspora studies and offers a renewed perspective on the study of overseas Chinese and Chinese overseas in a French context.

\section{$\mathbf{1}$ Chinese Immigrants in France and Recent Political Mobilization}

France is one of several European countries with a history of Chinese communities dating back to the beginning of the 2oth century. As in the UK and the Netherlands, this early Chinese presence in France can be explained by three main factors: colonization, the recruitment of Chinese laborers during the First World War, and the sojourn of students. This presence has had an impact on more recent waves of migration, the xin yimin, especially as a result of the Reform and Opening Up policy initiated in 1978 and the renewal of former migration networks from various parts of China in the 1980s. Wenzhou is the principle place of origin of Chinese migrants and their descendants in France. But the composition of the Chinese and ethnic-Chinese population in France is diverse in terms of both places of origin and migration routes. Today, the Chinese are the fifth most populous nationality among France's foreign 
residents, numbering 100,400 in 2016, and a total of 104,100 immigrants. ${ }^{2}$ As in the European Union in general (Thunø and Li 2020), the primary legal channel of entry to France for Chinese people today is the student visa: the Chinese are the second most numerous group of foreign students after Moroccans. ${ }^{3}$ Other migration routes include entry with a work visa, family reunification, and irregular migration channels (mainly people overstaying their tourist or business visa). Student mobility has inevitably led to a diversification of the locations of origin. Furthermore, France has also become the destination for a growing number of Chinese from northern China, especially from places hard hit by the withdrawal of the state from the economy, the restructuring of public enterprises, and the massive layoffs of the 1990s (Lévy 2012; Xiang 2007). One characteristic of the Chinese in France is the presence of a specific group of Chinese overseas from Southeast Asia who arrived as refugees from Cambodia, Vietnam and Laos after 1975. Cooperation between Chinese overseas from Southeast Asia and overseas Chinese from the People's Republic of China (mainly the city of Wenzhou) is important both within the diasporic entrepreneurial sphere (discussed in this issue by Li Zhipeng) and in the neighborhoods where these communities sometimes live together and often confront the same safety issues (Merle 2020). This cooperation is also enacted by the new generations born in France, through collective actions (see Le Bail and Chuang in this issue) which include mobilizing against the violence that targets members of the Chinese and other Asian communities.

These protests are one of the key contextual elements of this special issue. In 2010, 2011 and 2016 Chinese immigrants and their descendants organized street demonstrations denouncing violent and racist acts. Their feelings of powerlessness, combined with stereotypes about the other populations that inhabit the working-class neighborhoods (often communities from the Maghreb or sub-Saharan Africa), illustrate why safety has become a mobilizing cause within the Chinese community. Hence, in June 2010, after a cash robbery in Belleville escalated into a gun fight, a community process of self-identification was initiated on various social networks, prompting a large number of Chinese nationals and their descendants - of various social statuses and ages (entrepreneurs, teenagers and workers) — to take to the streets of Paris in protest and

2 Chinese foreign residents of France (defined as foreign nationals) and immigrants (defined as persons born abroad that may have taken French nationality or not) follow Algerians, Moroccans, Tunisians and Turks, excluding the case of other Europeans living in France and the specific case of Comorians in French overseas territories. Source: INSEE statistics online: https://insee.fr/fr/statistiques/4197229? sommaire $=4197305$.

3 Source: French Ministry of Education: https://publication.enseignementsup-recherche.gouv .fr/eesr/10EN/EESRıEN_ES_15-foreign_students_in_higher_education.php. 
to demand greater police protection. Since that initial attempt to draw attention to this collective sense of vulnerability, several more street protests have taken place (see Du, and Chuang and Merle in this issue). Additionally, when a significant number of French-educated second-generation youths joined the movement, the protests broadened out to include anti-racism messages, linking the common Chinese experiences of urban violence with Asian-targeted racism more generally - a form of racism which until then had not been acknowledged or recognized by the media, other anti-racist movements, or the public authorities (Chuang 2017, see Le Bail and Chuang in this special issue). The following is a chronological summary of these initiatives; the street protests and other collective initiatives, according to modes of action, locations, slogans and organizers:

TABLE 1 Collective actions in response to violence toward Chinese and Asian populations since 2010

\begin{tabular}{|c|c|c|c|c|}
\hline Date & $\begin{array}{l}\text { Forms of action } \\
\text { and location }\end{array}$ & $\begin{array}{l}\text { Incidents } \\
\text { motivating the } \\
\text { protests }\end{array}$ & Key slogans & Organizers \\
\hline June 2010 & $\begin{array}{l}\text { Protest in the } \\
\text { Belleville district } \\
\text { (Northeast Paris) }\end{array}$ & $\begin{array}{l}\text { Cash robbery } \\
\text { at a wedding } \\
\text { banquet }\end{array}$ & $\begin{array}{l}\text { "No to } \\
\text { violence, } \\
\text { yes to safety" }\end{array}$ & $\begin{array}{l}\text { Chinese } \\
\text { entrepreneurs' } \\
\text { associations }\end{array}$ \\
\hline $\begin{array}{l}\text { December } \\
2010\end{array}$ & $\begin{array}{l}\text { Creation of a } \\
\text { collective of } \\
\text { entrepreneurs in } \\
\text { the industrial zone } \\
\text { of Aubervilliers } \\
\text { (northern suburb } \\
\text { of Paris) }\end{array}$ & $\begin{array}{l}\text { Series of } \\
\text { thefts in the } \\
\text { wholesale } \\
\text { trading area }\end{array}$ & $\begin{array}{l}\text { "Solidarity } \\
\text { for safety" }\end{array}$ & $\begin{array}{l}\text { Chinese } \\
\text { entrepreneurs' } \\
\text { associations }\end{array}$ \\
\hline June 2011 & $\begin{array}{l}\text { Protest in the } \\
\text { central districts of } \\
\text { Paris (République- } \\
\text { Nation) }\end{array}$ & $\begin{array}{l}\text { Cash robbery } \\
\text { in Belleville, } \\
\text { in which } \\
\text { a Chinese } \\
\text { restaurateur } \\
\text { was seriously } \\
\text { injured }\end{array}$ & $\begin{array}{l}\text { "Safety is a } \\
\text { right" }\end{array}$ & $\begin{array}{l}\text { A Chinese } \\
\text { entrepreneurs' } \\
\text { association } \\
\text { distinct from the } \\
\text { one supported } \\
\text { by the Chinese } \\
\text { Embassy; the } \\
\text { Association of } \\
\text { Young Chinese } \\
\text { of France }\end{array}$ \\
\hline
\end{tabular}


TABLE 1 Collective actions in response to violence (cont.)

\begin{tabular}{|c|c|c|c|c|}
\hline Date & $\begin{array}{l}\text { Forms of action } \\
\text { and location }\end{array}$ & $\begin{array}{l}\text { Incidents } \\
\text { motivating the } \\
\text { protests }\end{array}$ & Key slogans & Organizers \\
\hline $\begin{array}{l}\text { August and } \\
\text { September } \\
2016\end{array}$ & $\begin{array}{l}\text { Protest in } \\
\text { Aubervilliers } \\
\text { (northern suburb } \\
\text { of Paris), then in } \\
\text { the central districts } \\
\text { (République- } \\
\text { Bastille) }\end{array}$ & $\begin{array}{l}\text { Death of Zhang } \\
\text { Chaolin, victim } \\
\text { of an assault } \\
\text { and street } \\
\text { robbery in } \\
\text { Aubervilliers }\end{array}$ & $\begin{array}{l}\text { "Security } \\
\text { for All" } \\
\text { "Prejudice } \\
\text { kills. Against } \\
\text { anti-Asian } \\
\text { racism" }\end{array}$ & $\begin{array}{l}\text { A collective } \\
\text { of Chinese } \\
\text { and Asian } \\
\text { associations, } \\
\text { spanning two } \\
\text { generations }\end{array}$ \\
\hline March 2017 & $\begin{array}{l}\text { Protest in front } \\
\text { of a police station } \\
\text { in the 19th } \\
\text { arrondissement } \\
\text { of Paris and a } \\
\text { memorial rally } \\
\text { at the Place de la } \\
\text { République }\end{array}$ & $\begin{array}{l}\text { Death of Liu } \\
\text { Shaoyao, } \\
\text { a resident } \\
\text { of the 19th } \\
\text { arrondissement, } \\
\text { killed by the } \\
\text { police in his } \\
\text { apartment }\end{array}$ & $\begin{array}{l}\text { "For truth, } \\
\text { against } \\
\text { police } \\
\text { violence" }\end{array}$ & $\begin{array}{l}\text { Chinese and } \\
\text { Chinese French } \\
\text { youths and } \\
\text { adolescents; } \\
\text { joined by } \\
\text { entrepreneurs } \\
\text { who sought } \\
\text { to calm the } \\
\text { youths' anger } \\
\text { and called for an } \\
\text { investigation }\end{array}$ \\
\hline March 2018 & $\begin{array}{l}\text { Creation of a } \\
\text { "Security for All } \\
\text { Committee" }\end{array}$ & $\begin{array}{l}\text { Series of thefts } \\
\text { targeting Asian } \\
\text { residents }\end{array}$ & $\begin{array}{l}\text { "For } \\
\text { increased } \\
\text { police } \\
\text { protection, } \\
\text { against } \\
\text { racism } \\
\text { targeting } \\
\text { Asians" }\end{array}$ & $\begin{array}{l}\text { Chinese French } \\
\text { and Southeast } \\
\text { Asian French } \\
\text { residents, of all } \\
\text { ages }\end{array}$ \\
\hline
\end{tabular}

SOURCE: DATA COLLECTED BY THE AUTHORS

From this aggregate account of the collective actions reported by the media, a trend emerges, showing the widespread nature of the issue of personal safety among the Chinese population. The protests initially took root in commercial districts, their focus only later shifting toward the violent robberies taking place in residential neighborhoods. Interestingly, the protests also moved from 
peripheral districts of Paris and its banlieues to more central and symbolic spaces (such as Place de la République), retracing the familiar routes taken by the demonstrations of France's left-oriented social movements. From the organizers' perspective, the concerns of the older generation of Chinese entrepreneurs (who have economic and social capital but little cultural awareness of how French institutions and media operate) have gradually been taken on by younger Chinese French activists, who are themselves much more familiar with French civic culture. This demographic shift among the protests' organizers and participants is also reflected in their slogans: whereas the first two demonstrations were primarily focused on safety-calling for an increased police presence and for security cameras to be installed-the involvement of the Chinese French youth from 2011 onward has gradually introduced the notion of equality and the issue of racism to the understanding of the roots of the violence. In turn, references to such violence within anti-racist demonstrations have also increased and broadened public support beyond the Chinese population (see Le Bail and Chuang in this issue). Subsequently, since the death of Zhang Chaolin in 2016, the phenomena of aggression directed at the Chinese population has become a legitimate category of public concern and has prompted the authorities to take action (see Chuang and Merle, and Du in this issue). Besides the visible actions of Chinese immigrants and their descendants, the profile of Chinese immigration is under transformation, predominantly due to student migration. For this sector of the population, and particularly its young graduates, discrimination and racism are issues of concern, especially in the workplace (see contribution by Li Yong in this issue).

The particular context of mobilization and calls for action in relation to violence and racism are the visible face of the intricate political issue of social cohesion and national community building. Not only do Chinese migrants and their descendants claim the right to equal recognition and protection, they also claim their place in the national narrative. Fighting the prejudice that portrays them as "eternal foreigners" is core to these descendants' cultural activism (Li 2007; Le Bail and Chuang in this issue), but the initiatives undertaken to demand inclusion in the national narrative also take more conventional forms. In particular, activists have campaigned for the Chinese Labor Corps to be mentioned during the ceremonies to commemorate the centenary of the Armistice that ended the First World War. In 2018 a statue was erected in Paris (near the area where the first "Chinatown" appeared after the First World War) in memory of the Chinese workers. The collective claims for recognition of belonging and the contribution of the Chinese French to the host society therefore raise new challenges to the universalist republican model of integration while at the same time questioning its color-blind doctrine. 


\section{The French Context in Global Debates: How the Supposedly "Model" Chinese Minority Came to Challenge the Universalist Republican Model of Integration}

The specific context of France is that of a country with a "republican model of integration" based on the political doctrine of color-blindness or ethnicblindness. In particular, the French model promotes a universal, expansive and assimilationist concept of citizenship in order to construct the nation (Brubaker 1992). For immigrants, such a model translates into an inclusive citizenship that is based on assimilation and presupposes that cultural differences do not constitute significant obstacles to constructing the political national community. This model implies that it could be divisive for the state to recognize and take into account differences in origins and for individuals to essentialize these differences with static categories. Consequently, public policies should be blind to or neutral towards citizens' ethnic or cultural origins and treat citizens as individuals without community belonging, other than belonging to the national community. However, the French republican model is today more an ideal type than a reality. As the influential sociologist Dominique Schnapper has observed, despite the constitutional obstacles that prohibit the recognition of minorities in France, several forms of de facto multiculturalist policies exist that draw on proxies for ethnic or racial categories (Schnapper 2015). Moreover, after years of intense debate among researchers (Héran 2017; Léonard 2014; Simon 2008), French socio-demographers eventually started using ethno-racial categorization with the aim of measuring discrimination quantitatively (see "Trajectories and Origins: survey on the diversity of French population,"4 Beauchemin et al. 2018).

In fact, whereas the republican model of integration was intended to be a tool of social cohesion that reduced unequal treatment and the risk of communitarianism, it is today criticized for being responsible for reproducing inequalities. The ideals of universalism, and in particular "color-blind" statistics, have been criticized in France and beyond for merely hiding ethnicracial inequalities (Léonard 2014); other critiques claim that the color-blind approach enables white privilege to be maintained (see Feagin 2013; Chou and Feagin 2009, and their notion of the "white racial frame"), upholding the structural sources of racism. In the words of the French sociologist Patrick Simon, " $[\mathrm{n}] \mathrm{o}$ one would contest the fact that the absence of the official use of ethnic or racial categories fails to curb the spread of prejudice and stereotypes. The main

4 Survey website: https://link.springer.com/chapter/10.1007/978-3-319-76638-6_1. 
result of the social and statistical invisibility of 'race' and ethnicity may well be to conceal the extent of discrimination" (Simon 2008: 8).

These debates, although until now particularly focused on the racism and discrimination experienced by the Black and North-African populations, are in fact also relevant for the Chinese and more generally the Asian population in France. The Chinese and Asian populations are often considered as living examples of the republican model of integration (just as Asian Americans are said to embody the "American dream" in the U.S.). However, such a stereotype of a model minority is itself ambiguous and double-edged.

First, it disseminates an essentialized and monolithic image of all the Chinese and Asian populations, which are considered to be a model minority as a whole, thus racializing people of Chinese or Asian origin and implicitly opposing their supposedly "successful" integration to the allegedly "failed" or "incomplete" integration of other immigrant groups. The core of the republican model is equality of opportunity for individual success, conceived in terms of educational performance and professional achievement. In France and many other countries the descendants of Asian immigrants are perceived as having better educational outcomes than other immigrant minority groups ${ }^{5}$ and of being hard-working populations. As a result, in French political discourse they are labeled as the embodiment of the republican model. These clichés were illustrated in former French president Nicolas Sarkozy's speech at Chinese New Year in 2010, where he publicly congratulated the Asian community:

You, my friends, have become the model of successful integration.... Each of you, in your professional field, embodies the work ethic that I cherish, the fostering of which is fundamental to achieving successful integration. ${ }^{6}$

Paradoxically, their professional success is also a source of stigmatization. In France as in numerous other European countries, Chinese new migrants who left China after the Reform and Opening Up policy have achieved upward social mobility by making use of diasporic networks and an ethnic economic model. From restaurants to wholesale markets, their economic activities have

5 Regarding the educational attainment of the children of immigrants in France, see Mathieu Ichou 2016. The cliché is, however, challenged by recent surveys: see Yamamoto 2015 and Yiu 2013 .

6 Pierre Haski, "Sarkozy félicite les Chinois pour leur 'intégration réussie"” [Sarkozy congratulates the Chinese for their 'successful integration'], Rue 89/L'Obs, https://www.nouve lobs.com/rue89/rue89-monde/20100217.RUE5089/sarkozy-felicite-les-chinois-pour-leur -integration-reussie.html. 
contributed to reshaping urban territories through the creation of ethnic enclaves. While promoting the social mobility of immigrants, Chinese ethnic entrepreneurialism and the spatial concentration of the Chinese ethnic economy has sometimes provoked negative perceptions among local residents and the public in general. Tensions have even arisen in Paris (the case of the 11th arrondissement studied by Chuang and Trémon 2013), in the Chinatowns of London and Milan (Hatziprokopiou \& Montagna 2012), and more recently in various Central and Eastern European countries (Liu 2020).

Secondly, viewing Asians as a model minority tends to overlook their experiences of racism and discrimination, especially in the context of the French color-blind policy. Various sociologists have pointed out that this "colorblindness" makes it difficult to acknowledge and react to racism and discrimination (e.g. Fassin 2006). Recent debates around the "Black Lives Matter" movement continue to reproduce such a model: while the disadvantaged youth of underprivileged neighborhoods have denounced police violence through mass protests, the French president Emmanuel Macron has openly criticized the academic work on race and discrimination for "creating social problems and tensions." ${ }^{7}$ Such a reluctance to admit to the existence of racism and racial discrimination in French society not only has an impact on young people of African descent (the group most commonly subjected to police violence) but is also becoming increasingly relevant in the case of Asian youth, especially those of Chinese origin, the supposedly "model minority," leading this group to reflect on and react to the discrepancy between the official discourse and their everyday experiences, thereby paving the way for dialogue and alliances between different racialized populations.

\section{3}

\section{Overview of this Special Issue}

This "generational turn" constitutes the point of departure for this special issue. Drawing on ethnographic fieldwork and in-depth interviews, the five articles analyze various forms of discrimination experienced by the new Chinese migrants - first and second generation included - and their strategies of resistance. They offer different perspectives on the political socialization and mobilization of the Chinese and their descendants in France: while Juan Du, Ya-Han Chuang and Aurore Merle analyze the mobilization processes and patterns of first-generation Chinese immigrants in the "banlieues rouges" (red/

7 http://www.lesinrocks.com/2020/o6/11/actualite/societe/macron-juge-le-monde-uni versitaire-coupable-davoir-casse-la-republique-en-deux/. 
communist suburbs) of Paris where many Chinese migrants live and work today and face cohabitation and safety difficulties in relation to other population groups, Hélène Le Bail and Ya-Han Chuang show how Chinese and Asian descendants (second or 1.5-generation immigrants) use social networks to share their feelings about their belonging and discuss the discrimination they suffer, with the online gatherings leading to anti-racist legal actions. These five articles provide insight into how various collectives of Chinese-French activists, from different generations and diverse social backgrounds-residents, small-scale entrepreneurs, marginalized inhabitants, and students, as well as the media and cultural elite - and with different resources and repertoires of actions, challenge central institutions in France's democratic life: the city hall and its mayor, the police, the courts and the media. Through their actions, not only do these concerned and mobilized citizens become more familiar with French civic life but they also contribute to transforming and enriching it, by calling out racism and discrimination and advocating new patterns of inclusion and citizenship.

Yong Li's contribution highlights the individual processes that Chinese graduates go through to identify and call out the racial discrimination and sometimes outright racism that they experience in the workplace and the responses they develop in relation to their bosses and colleagues. This growing consciousness facilitates collective mobilization against anti-Chinese racism, as analyzed by Le Bail and Chuang, and has led to alliances with other antiracist organizations and actors. Zhipeng Li's article, which takes a detailed look at two overseas-Chinese ethnic media organizations in France, shows how these media provide Chinese xin yimin with a platform to express themselves and share common feelings of belonging/non-belonging in France and China, thus contributing to the organization of community life. As Du and Chuang and Merle illustrate in their articles, Chinese ethnic or community-based mobilizations are not an expression of communitarianism or of separatism from the national (French) community; on the contrary, they collectively voice a wish to be an integral part of the host society. In this sense, they largely contribute, in conjunction with the actions of other groups of citizens, to reframing the French republican model by demonstrating that universalism and equality are compatible with multiculturalism and diversity. There is still a long way to go and the various forms of political participation of the "Chinese-French" will continue to require further scrutiny. 


\section{Acknowledgements}

This special issue has been realized thanks to financial support from the City of Paris Emergences research grant "Chinese of France: identifications and identities in transition" 2018-2020) and the CY Cergy Paris University.

\section{References}

Beauchemin, Cris, Christel Hamel and Patrick Simon (eds). 2018. Trajectories and Origins: Survey on the Diversity of the French Population (vol. 8). Cham: Springer.

Brubaker, Rogers. 1992. Citizenship and Nationhood in France and Germany. Cambridge, Mass.: Harvard University Press.

Chuang, Ya-Han and Anne-Christine Trémon. 2013. "Chapter Seven Problematizing 'Chinatowns': Conflicts and Narratives Surrounding Chinese Quarters in and around Paris." In Chinatowns around the World: Gilded Ghetto, Ethnopolis, and Cultural Diaspora, eds, Bernard P. Wong and Chee-Beng Tan, pp. 187-214. Leiden: Brill.

Chou, Rosalind and Joe R. Feagin. 2015 (2d edition). The Myth of the Model Minority. Asian Americans Facing Racism. Boulder, CO.: Paradigm.

Chuang, Ya-Han. (2017). La Colère du middleman : quand la communauté chinoise se manifeste (The Middleman's Rage: When the Chinese Community Speak Out). Mouvements (4), 157-168.

Fassin, Eric. 2006. "Aveugles à la race ou au racisme? Une approche stratégique (Blind to Racism? A Strategical Approach)." In De la question sociale à la question raciale (From Social Issue to Racial Issue), eds, Didier Fassin and Eric Fassin, pp. 106-130. Paris: La Découverte.

Feagin, Joe R. 2013 (2nd edition). The White Racial Frame Centuries of Racial Framing and Counter-framing. New York: Routledge.

Hatziprokopiou, Panos and Nicola Montagna. 2012. "Contested Chinatown: Chinese Migrants' Incorporation and the Urban Space in London and Milan." Ethnicities 12(6): 706-729.

Héran, François. 2017. Avec l'immigration. Mesurer, débattre, agir (Immigration. Measures, Debates, Actions). Paris: La Découverte.

Ichou, Mathieu. 2016. "Migration Background and Educational Inequality: A Longitudinal Study of the Academic Achievement of Children of Immigrants in France and England." Revue française de pédagogie 191(2): 29-46.

Laczko, Frank. 2003. "Introduction: Understanding Migration between China and Europe." International Migration 41(3): 5-19.

Léonard, Marie des Neiges. 2014. "Census and Racial Categorization in France: Invisible Categories and Color-blind Politics." Humanity and Society 38(1): 67-88. 
Lévy, Florence. 2012. "The Migration of Women from Northern China: A Genderoriented Choice?" China Perspectives 4: 43-51.

Li, Xiaoping. 2007. Voices Rising: Asian Canadian cultural activism. Vancouver: UвC Press.

Liu, Amy H. 2020. "Public Attitudes and the Chinese Migrants in Central-Eastern Europe." International Migration 58(3): 118-133.

Ma Mung, Emmanuel. 2012. "Temporal Continuity, Spatial Contiguity and Creation of a World That is Specific to a Social Entity: the Case of the Chinese Diaspora." Espace géographique 41(4): $35^{2-368 .}$

Merle, Aurore. To be published. “S'engager dans son quartier: La mobilisation d'habitants d'origine chinoise et du sud-est asiatique à La Courneuve, Seine Saint-Denis (Getting Involved in their Neighbourhoods: Mobilization of Chinese and Southeast Asian Residents in La Courneuve, Seine Saint-Denis)". In La Globalisation chinoise en (Ile de) France. Mobilités, ancrages spatiaux et enjeux urbains (Chinese Globalisation In France. Mobilities, Spatial Anchoring and Urban Challenges, eds, Ya-Han Chuang and Anne-Christine Trémon. Terra-HN éditions.

Schnapper, Dominique. 2015. "Quelle politique multiculturelle? (What Kind of Multicultural Policy?)." Le Débat 186: 111-121.

Simon, Patrick. 2008. "The Choice of Ignorance. The Debate on Ethnic and Racial Statistics in France." French Politics, Culture \& Society 26:7-31.

Thunø, Mette and Minghuan Li. 2020. "Introduction: New Dynamics of Chinese Migration to Europe." International Migration 58(3): $5^{-21}$.

Tran, Émilie and Ya-Han Chuang. (2020). Social Relays of China's Power Projection? Overseas Chinese Collective Actions for Security in France. International Migration $58(3), 101-117$.

Xiang, Biao. 2007. "The Making of Mobile Subjects: How Institution Reform and Outmigration Intersect in Northeast China." Development 50 (4): 69-74.

Yamamoto, Sumiko. 2015. "School Success and Failure: Changes Seen in Children of Chinese Descent in Paris." Journal of Chinese Overseas, 11(1): 56-70.

Yeh, Diana. 2014. “Contesting the 'Model Minority': Racialization, Youth Culture and 'British Chinese'/'Oriental' nights.” Ethnic and Racial Studies 37(7): 1197-1210.

Yiu, Jessica. 2013. "Calibrated Ambitions: Low Educational Ambition as a Form of Strategic Adaptation Among Chinese Youth in Spain." International Migration Review 47(3): 573-611.

Zhou, Min and Hong Liu. 2016. "Homeland Engagement and Host-Society Integration: A Comparative Study of New Chinese Immigrants in the United States and Singapore." International Journal of Comparative Sociology 57(1-2): 30-52. 